\title{
Putting Belonging into Place: Place Experience and Sense of Belonging among Ecuadorian Migrants in an Italian Alpine Region
}

\author{
ROBERTA RAFFAETÀ \\ Università di Trento \\ CAMERON DUFF \\ Monash University
}

\section{Abstract}

This paper explores the meaning and mechanics of belonging with a particular focus on the role of place and place-making. It explores the ways people come to achieve a sense of belonging with reference to recent theoretical treatments of place, territory, and mobility. We ground our discussion in analysis of an ethnographic case of Ecuadorian families who have migrated to Trentino in northern Italy. Most families miss the social relationships and places they left behind, but have decided to stay permanently in Italy, giving up the "myth of return" (Anwar 1979). Trentino offers more opportunities in term of employment, education, and access to services than Ecuador. Yet the decision to stay in Trentino is based on more than a simple assessment of economic advantage. Participants spoke of a slowly unfolding sense of belonging to Trentino, with strong affective dimensions born of a specific attachment to the very materiality of place in Trentino. This attachment may be regarded as an assemblage of social, material and affective resonances, experiences and resources, revealing something of the place and feeling of belonging. Hence, the Ecuadorian sense of belonging does not rely on an abstract conception of cultural affiliation, nor is it a purely psychological response. Rather, belonging accrues in particular practices and material attachments. We unpack these practices by documenting the work participants put into inhabiting an unfamiliar place as "their" place, while at the same time questioning the ontological status of space. [affect, Ecuador, Italy, transmigration, place-making]

D uring a meeting hosted for new immigrants by local political authorities in Val Rendena in Northern Italy, the president of the Valley Community (Comunità di Valle) welcomed immigrants as "substantial creators of the local wealth" and encouraged them to share their needs and aspirations regarding their lives in Val Rendena. The president added:

You have arrived in a rich land. Here you can create your family, plan a future and, possibly, also send money home. . . . It is important not to forget your roots, but it is also important that you feel Italian, that you feel well here, that you feel that this community is your community (emphasis added)! What can we do for you? 
The president's remarks elicited a range of comments, including requests for better employment and housing opportunities from members of the local Moroccan community. Yet the Ecuadorians present spoke of one issue with particular insistence: the lack of public places for families to play soccer, basketball, and volleyball, and places to enjoy a rich social life outdoors. The manner in which this issue was presented made it apparent that the desire for more outdoor public space was a pressing problem for many members of the local Ecuadorian community.

The president of the Valley Community betrayed some surprise at this request. She went on to speak of the abundance of open spaces in Val Rendena, suggesting that local residents ought to join the tourists who come in great numbers to escape the crowds and chaos of the city and who enjoy the silence of the mountains and the solitude of the forest. The president went on to extol the virtues of the valley, its wonderful mountain tracks and wild nature which are envied by people all over the world. She then proposed organizing a guided tour for immigrants so that they might discover this beauty too. The Ecuadorians present subsequently confided to me (Roberta) that they felt misunderstood. They were looking for public space in the village, not in the mountains. They desired public spaces where the community, including children and elders, could easily gather, and places where people could sit, gossip, or play soccer, if they wanted to. The Ecuadorians in the audience were clearly aware that Val Rendena is surrounded by mountains. But they were looking for something else, something that was not captured by the president's valorising descriptions of the valley's natural beauty and its popularity among tourists. The Ecuadorians seemed to be talking about a place where a sense of social life and belonging could flourish, where family relationships could be strengthened and community could be formed. While the president's remarks emphasized the emergence of Val Rendena as a world-class tourist destination, Ecuadorians appeared to be interested in a different set of material resources and different kinds of places. This article explores these different perceptions and expectations of place, drawing from recent theoretical treatments of space, territory, and mobility in cultural anthropology, human geography and allied disciplines. Our goal is to shed light on the social, material, and affective dimensions of place and place-making in order to advance an understanding of how feelings of belonging are achieved in a transmigrant community.

\section{Belonging and space}

$\uparrow$ he concept of belonging is particularly salient in current debates concerning the character of transnational migration (Yuval-Davis 2004). The increasing mobility of people and cultures around the world has undermined established notions of belonging and security, leading many to question the relationship between belonging, culture, place, and territory (Geschiere 2009; Nyamnojoh and Geschiere 2000). New frameworks of analysis (Yuval-Davis 2006) have emerged in 
response to these challenges, more cognizant of the performative dimensions of belonging (Krause and Schramm 20II). In line with these efforts, this paper explores the meaning and mechanics of belonging with a particular focus on the role of place and place-making. We ground our discussion in an ethnographic analysis of Ecuadorian families that have migrated to Trentino in northern Italy. We have selected this community for analysis in light of its members' interest in accessing public space in Val Rendena. Their public expressions of a desire for public space provide a timely opportunity to examine questions of place, belonging, and culture in the context of transnational migration in Italy. Using ethnographic data, our goal is to identify the particular practices and strategies participants employ in the work of inhabiting an unfamiliar space as "their" place.

Even though Maurice Leenhardt introduced the notion of the "social landscape" in the I940s (I979 [I947]), it was not until the I980s that anthropologists, inspired by the work of Marxist urban geographers (Castells i977; Harvey i973), became more sensitive to the dynamics of space and place and the role of practice in the cultural construction of place (Appadurai 1988; Lawrence and Low I990). Interest in these themes has blossomed in the intervening years, particularly in relation to the study of globalization and the practice of multi-locale ethnography (Clifford 1997; Gupta 1997; Hastrup and Olwig I997; Marcus 1989). In an apparently unbounded and globalized world, the need to accommodate the problems of fluidity and movement in attempt to account for space and place has become especially urgent (Gieryn 2000; Gustafson 2006). Of particular importance has been the need to overturn the idea of space-as-distance, in light of various theoretical and empirical projects which refuse to reduce the former to the latter. Doreen Massey argues, "space is more than distance. It is the sphere of open-ended configurations within multiplicities" (2005:9I ). This idea has been especially important in recent anthropological accounts of transnational flows of people, goods, knowledge and practices, and the various disjunctions and innovations associated with these movements. Analyses of these kinds of flows suggest very strongly that movement needs to be conceptualized in terms of the mobility of "lifeworlds." This includes people's social relationships, cultural beliefs, affective investments, values and attachments, in addition to material resources (Corsin Jiménez 2003:I40). Mobility is meaningful, in this sense, for anthropologists because it is understood in terms of "existential mobility" instead of merely "physical mobility." Each of these dimensions is crucial to the migration experience. Ghassan Hage observes, "to sense that one's movement across international borders is significant it has to involve a sense of being uprooted from things that one is familiar with and a sense of being out of place" (2005:470). This calls attention to the complex relations between space, affect, attachment, place, and belonging in the material experience of space and place (Massey 2005; Thrift 2004).

Usually construed in terms of an apparently stable, objective, and material reality, space has been understood in recent scholarship more 
in terms of relationality, proliferation, and construction, and as a property of social relationships, material practices and symbolic meaningmaking (Corsin Jiménez 2003; Kahn I990; Leach 2006; Myers 2000; Rodman I992). Jeff Malpas argues that the very ontological status of space is disrupted in this kind of research (2012:5-7). While this "relational" turn (Anderson and Harrison 2010) has been highly influential, critics decry its apparently anthropocentric bent, and its neglect of the non-human constituents of place. The fear is that a purely subjective, relational, or affective account of place risks relegating the grounded solidity of space "into the air of social and cultural construction" (Lund and Benediktsson 20Iо:I). Even so, an over-reliance on the materiality of place ignores various social and affective strategies by which place is made meaningful in everyday ways of inhabiting space (Thrift 2004). Recent debates regarding the ontological status of space and place thus draw attention to a range of objective and relational properties and processes, suggesting that space ought to be understood both as a resource or ground for social relations, as well as the product of those same relations (Conradson 2005; Johannesdottir 20I0). In framing the problem of space in the context of the present study, we join with Lund and Benediktsson in considering space as a "more-than-human-materiality" (2010:I). In particular, we focus on the notion of space as resource, which acknowledges the material dimensions of place alongside its relational, social, and affective constituents.

Our understanding of space and place takes further inspiration from recent efforts to characterize those dimensions of place which actively promote or facilitate the experience of health and well-being. This includes work in geography and sociology on "therapeutic landscapes" (Gesler I992; Williams I999; Williams 2007), research in environmental psychology on "restorative places" and "restorative experiences" (Hartig and Staats 2003; Korpela and Hartig i996), as well as research on "enabling environments" (Tawil et al. I995) and the various ecological features of place which promote or enhance human development (Conradson 2005; Duff 2009). Work in each of these domains indicates that place ought to be regarded as a fundamental feature of human experience, deeply implicated in the processes of identity formation and belonging, health, and well-being.

Taken together then, research on belonging and transnational migration, mobility, space, and place-making, as well as research into the therapeutic or enabling aspects of space and place suggests to us the importance of regarding place as a social, material, and affective achievement. Place may be fixed in a material space or territory, just as it is made in a complex web of social and affective relations and attachments. Above all else though, the scholarship introduced briefly above indicates the importance of culture and practice in the experience (or making) of place. This formulation has important implications for thinking about belonging in the context of transnational migration, shaping both our research design and our data analysis.
Putting Belonging into Place: Place

Experience and Sense of

Belonging among Ecuadorian Migrants in an Italian Alpine Region 


\section{Background and context of the study}

ost Ecuadorians in Val Rendena migrated from the province of
El Oro in the coastal south-west region of Ecuador, near the
border with Peru. Financial instability in the late I99os and into the 2000 s led more than a million Ecuadorians to emigrate (seven percent of the national population), mostly to Italy, the United States, and Spain (Boccagni 20 I Ia: I). In Italy, most of the Ecuadorians settled in Genova, Milan, and Trentino. While in Trentino, they settled either in Trento, the most populous city in the region with around I 6 , o o inhabitants, or in Val Rendena, a valley located in the south-west of Trentino with around 20 villages. Trentino has a history of significant political and economic autonomy. Living standards across the region are generally higher than other parts of Italy. With the World Heritage listed Dolomites, the Italian Alps, and extensive alpine forests and lakes, Trentino also supports a thriving tourism sector. There is strong national and international demand for snow sports in the winter, and climbing and hiking in the summer, spring, and autumn. Trentino has around 48,000 migrants, or roughly nine percent of the provincial population (Ambrosini, et al. 20 I I). The total population in Val Rendena is almost I0,000. 587 are migrants, with approximately 137 hailing from Ecuador (almost a quarter of the total number of migrants). ${ }^{\mathrm{r}}$

International migration to Italy has increased significantly since the I 980 (Colombo and Sciortino 2004), eliciting varying degrees of acceptance among local populations (Sciortino and Colombo 2004). In recent years, the Berlusconi government and the Lega Nord party, in particular, occasionally exploited fears about migration among sectors of the Italian community. While large influxes of migrants have been common in Italy's larger urban centres for decades (Sciortino and Colombo 2003), in smaller regional settings like Val Rendena, migration is a far more recent

Some locals in Val phenomenon. Like in other regions of Italy, some locals in Val Rendena welcome new migrants while others express concerns about potential Rendena welcome threats to the traditional culture and values of the existing residents. This has led to significant political debate in Val Rendena as locals and new migrants

while others new-comers alike argue about the challenges and opportunities occasioned by growing migration in the region.

express concerns

about potential

Research design: Aims, methods, and procedures

threats to

traditional culture

T his study is based on ethnographic data collected between 2010 and 2013 on the experience of immigration and parenting among a sample of 17 Ecuadorian families in Val Rendena. Various strategies and values were employed to ensure that diverse families were recruited across the valley, including the promotion of the study at local family health and social services, the Val Rendena multicultural association, and through our personal networks. Initial participant contact was complemented by snowball recruitment as primary research participants promoted the study 
through their own family and social networks. Inclusion criteria were as follows: participants were required to be currently living in Val Rendena, to have been born in Ecuador, and to have one or more children aged six years or younger. Consistent with these criteria, participants were between 22 and 42 years old, with a mean age of 25 . Of the 17 families recruited for the study, 15 were "closed" in that all members were Ecuadorian. One family was mixed with an Ecuadorian woman married to a local Italian man. Another family was headed by a single parent (mother).

A three-stage methodology was devised to explore participants' experiences of migration, involving in-depth interviews, participantobservation and photo-elicitation according to the "photo-voice" method introduced by Wang and Burris (1997). Initial contact with families typically commenced with mothers. They were more available than fathers who tended to be unavailable due to their work commitments. Interpersonal dynamics in Ecuadorian families are organized according to traditional gender roles. My (Roberta) visibility as a young mother in the community helped establish rapport with local Ecuadorian women. Once these contacts had been established and participantobservation had commenced, opportunities arose to interview fathers. Interviews were conducted in Italian and Spanish, depending on the interviewees' preference. A participant information and consent protocol was administered prior to the start of interviews.

Early contact with Ecuadorian community members, especially women, created opportunities for more extensive participant-observation. I, accompanied by my three-year-old daughter, often met local Ecuadorian mothers and their children at local playgrounds or in their respective houses. Following these initial encounters, I was invited to attend weekend community gatherings, various parties, and community celebrations. I also attended public meetings organized by a multicultural association operating in Val Rendena, and I volunteered to teach Italian at an association offering language classes to newly-arrived migrants.

Issues of space and place emerged as key themes throughout the interviews and observational research. In order to explore these themes more deeply, we employed visual methods including photo-elicitation to document local places and as a prompt to advance discussions about the links between place, community, and belonging. Visual techniques offered a creative means for understanding and describing experiences, feelings, and symbolic interactions which are often difficult to talk about. We were also conscious of recent calls for more innovative methods to trace the interplay between environmental, social, and affective dimensions of place and place-making (Conradson 2005; Cummins et al. 2007; Fogel et al. 2008; Macintyre et al. 2002). Visual methods like photo-voice are particularly apt for understanding place experiences, with emerging evidence suggesting that they are especially well suited to tracing the embodied, material, and affective dimensions of place and belonging (Pink 2006; Tolia-Kelly 2007:344). Consistent with the photo-voice method, we asked participants to take pictures of local places they particularly liked or felt attached to. Of the i 7 families interviewed for the study, ten elected to
Putting Belonging into Place: Place

Experience and Sense of

Belonging among Ecuadorian Migrants in an Italian Alpine Region

Participants took pictures of local places they particularly liked or felt attached to 
participate in the photo-voice research. Each was offered a disposable camera although eight elected to use their own camera.

All data sources were integrated according to the steps described by Yin (2006) and Woolley (2009) for the management of mixed-method data. The resulting dataset was then analysed using a series of techniques drawn from the "situational analysis" introduced by Adele Clarke (2005). Situational analysis permitted more sensitive treatment of each participant's report of place and belonging, while leaving open the possibility of fresh theoretical insights and novel theory development. Data analysis involved open, axial, and selective coding to identify and explore the various dimensions of place and belonging described by participants. This included "constant, comparative" analysis (Liamputtong and Ezzy 2005) of regularities, variations, and contrasts in the data to test and confirm emerging insights regarding the characterization of belonging and the role of place in belonging and community attachment. As codes and themes were slowly established, we were led to a more refined analysis of the data. The quotations cited below are taken from our data and reflect our own translations from Italian and Spanish to English.

\section{Place as sociality}

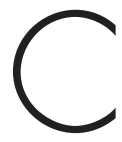

onsistent with the theories of space and place introduced above, our analysis of place-making in the accounts of our participants commenced with the social aspects of place. Val Rendena's natural beauty attracts tourists all year round, which drives the local economy. However, the natural environment is reportedly of little interest to the Ecuadorian migrants who participated in our study. Our participants, in contrast, report a desire for communal space in the village, places with benches and tables for the community to come together. They speak of the importance of the collective use of public spaces to promote socialization, recognition, and the collective organization of local identities. Without denying the beauty of the mountains, Val Rendena does not appear to offer the same opportunities for local Ecuadorians as it does for wealthy international tourists.

Parties are a central feature of community life in Ecuador (Pallares 2005), and our participants speak of attempts to maintain this tradition in Val Rendena. Parties and leisure time safeguard the cohesion of a transnational community that may otherwise fragment (Boccagni 2010). They are occasions to perform what Boccagni calls "emotional patriotism," which is "concerned less with the motherland, than with the ways of reproducing, and turning into real social practices, the reminiscences that Ecuador elicits overseas" (20 I I b:92). The energy and time devoted to the organization and attendance of parties illustrates their importance to the expatriate community, and their role in maintaining in-group social capital. The Ecuadorians who participated in our study endorse the role of local celebrations in maintaining and extending social ties within the wider Ecuadorian community in Val Rendena. The celebration of family life through key milestones like pregnancies, 
births, anniversaries, and birthdays is described as the primary means of cultivating community ties. Participants speak of the importance of dancing, socializing, sharing food, and the role of games (concursi) in strengthening relationships and building a sense of communal identity. These parties typically involve great expenditures for families, even though each guest or family offers to help cover the cost by giving money. Participants observed that without these regular celebrations, opportunities for social interaction are limited. Community members are typically busy during the week with work, and the geographic dispersal of the community throughout Val Rendena makes it difficult for individuals to see one another outside of planned events.

In the summertime, however, opportunities for community interaction reportedly increase, particularly on Saturdays. According to our participants, families meet in public places where the men play soccer, or a special version of volleyball which they call "Ecuvolley," while the women congregate under the sun and chat as their children play freely. Commonly, someone leaves their car open to play Latino music at high volume, and someone else brings beer. Every second Saturday a peddler from Milan comes to these events with his car full of Ecuadorian food specialities: pilchards in tomato sauce, Sabor Tropical (an Ecuadorian red and sparkling soft drink), peanut butter, Ecuadorian biscuits, and various colourful fruits and vegetables like platano verde, fresh coriander, avocado, limes, papayas, maracuyas, and chirimoyas. The availability and accessibility of public space for social interaction are described as crucial issues for participants. Participants speak of meeting in past summers in the village pinewood. This is an open space enclosed with pine trees, offering various facilities including a large soccer field, fountains, and a playground. The soccer field, however, ostensibly only available to the local soccer team for official matches, and during the summertime it was reserved for the professional Italian teams that come to Val Rendena to train. The soccer teams typically attracted masses of tourists and fans. A few years before the start of this study, this influx of visitors prompted the local mayor to forbid Ecuadorians to gather in the pinewood. Instead, they were directed to another open space outside of the village. Since then only Ecuadorians use this area. During the winter, the local Ecuadorian community usually moves indoors to a local dance hall with a kitchen. The cost of renting these spaces is shared among community members.

The accounts provided by our participants suggest a stark contrast in the ways public places are used and understood by Ecuadorian migrants and other residents of Val Rendena. For Ecuadorians, public places are central to the maintenance of social relationships. Yet, echoing the President of the Valley Community's remark reported above, other residents regard public space in terms of the value tourists ascribe to the region's natural beauty. This way of valuing public space is consistent with how the valley is represented in tourist advertisements and other promotional materials. In his book Tristi Montagne, Christian Arnoldi (2009) reveals the dislocation and social exclusion that so often

For Ecuadorians, public place is central to the maintenance of social relationships; other residents regard public space in terms of the value tourists ascribe to the region's natural beauty 
accompanies efforts to transform alpine regions like Val Rendena into "Disneyworld" for tourists. These efforts are confirmed by observations made during my long-term residency in Val Rendena and my dual positioning as an insider (having lived there for more than 20 years) and an outsider (not being born there and also having lived abroad). Val Rendena appears suspended between an apparent refusal of old traditions and a never fully reached conversion to modernity. Indeed, sociality in Val Rendena is still largely maintained by kinship relationships and by one's membership within special groups. It is notable that houses in Val Rendena are often luxurious, very well cared for, serving as a source of family pride and a measure of private wealth. But they are also spaces of privacy and social exclusion. Community relationships are regulated by strict social conventions derived from a tradition of respect for domestic intimacy. Ecuadorian participants in our study note that public expression of emotions and the sharing of inner thoughts are discouraged in Val Rendena. This further contributes to their sense of being different from local residents. Ecuadorian participants lament the prevailing social codes in Val Rendena and speak openly of missing the vibrancy of Ecuador's social and cultural climate. Carla sums up this sentiment:

It is what I miss, you know, (back home) I would go out and everybody would say "hello, hello." I was never closed in my house. We never stayed long in the house. Instead here one is always shut in. . . It is all another thing. Here there is silence and peace, but there [in Ecuador], there is always chaos. Everybody has their radio playing, but nobody says anything because it is a normal thing. Perhaps the neighbors finish their salt and come over to ask you for some. You know, it is another . . . is another life. . . W With my son I try to leave some music on, you know. I try to treat him, to get him thinking differently, to grow him up a bit cheerful, a bit open, not too much closed as they are here.

\section{Place as materiality}

he contrast in the ways local Ecuadorians conceive of place in Val
Rendena is further conveyed in the photographs they took as part
of the study. These highlighted the material aspects of space valued
by Ecuadorians. Largely ignoring the wilderness, mountains, and forests,
participants document the civic order of the village instead. For example,
Rosa, 24, a resident in Val Rendena for only two years, was pregnant at the
time of the study and spent much of her time caring for her three-year-old
son. Rosa's photographs portray the order of civic life in Val Rendena, like
the local system of separate refuse collection (see Figure I):

When I first saw it I could not believe my eyes! You not only collect your garbage, but even collect it separately! Here everything is so quiet, so clean, all over the streets. Here it is more safe for Mathias [her child]. There [Ecuador] is dirt all around. In certain parts you can find accumulated garbage and this, the noxious fumes, are harmful to your health. 


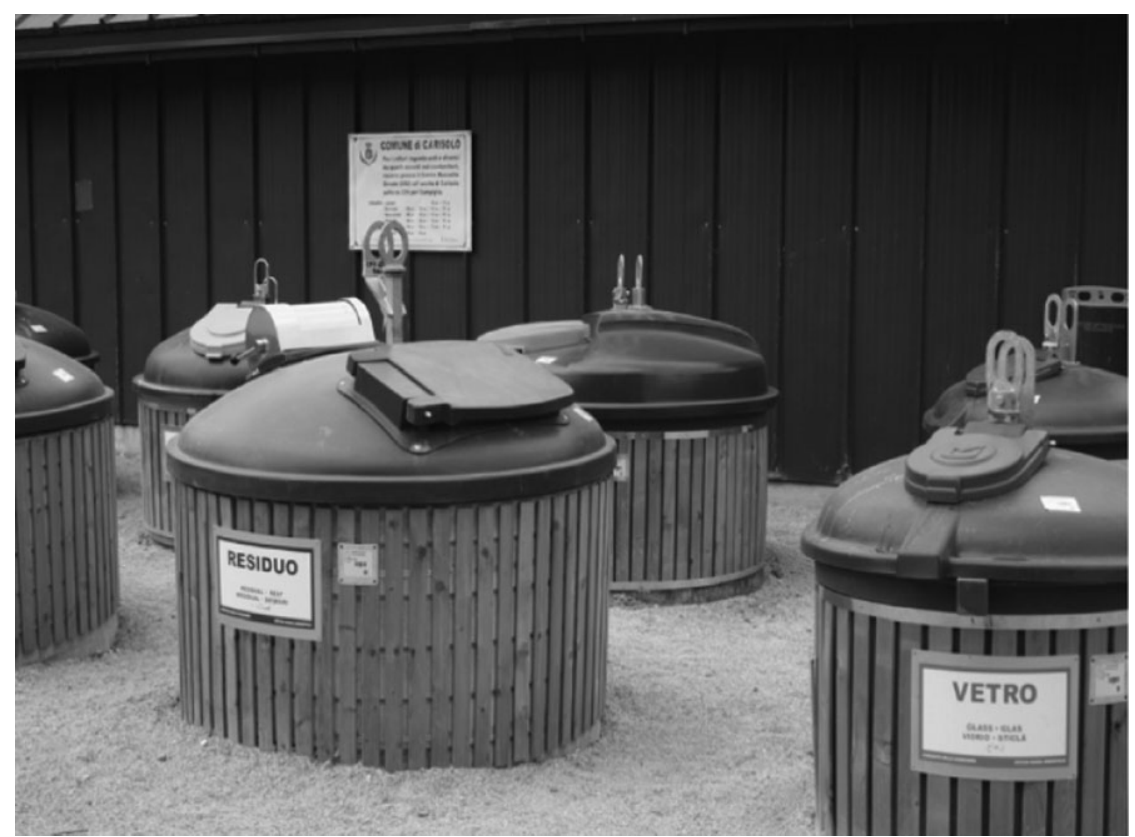

Figure I. Rosa's picture. The local system of separate refuse collection.

Rosa's husband had moved to Val Rendena three years prior, after his mother, who had lived in Val Rendena for 15 years, convinced him to come. Rosa and her husband, like other participants in the study, had initially planned to move to Val Rendena, make some money, and then return to Ecuador to build a house. Since her arrival, however, Rosa felt she would like to stay forever. She said, "I feel well here. I miss my family, but I feel better here; it's a better place to live with my family."

A number of participants note the cleanliness of public spaces in Val Rendena, describing this as an indicator that safety, civic order, and healthy living is promoted in the village. Victoria, 33, came to Val Rendena in 200I to join her cousin who had found work for her in the area. Victoria later married a local Italian man, and they now have a two-year-old child. Victoria notes that in Ecuador there are few possibilities for her. She had not wanted to become a burden for her parents, so she quit her university studies and left for Val Rendena:

When we arrived here we all had a fixed idea: to make some money and stay here two to three years. But you see, years went by and we are still here [she laughs]. Here all is quiet and clean. In Ecuador there is a lot of criminality; it is not a safe place. I think that I would have remained here even if I had not married an Italian man.

Like Rosa, Victoria describes Val Rendena as a place full of resources, noting that this relative prosperity has contributed to her developing sense of belonging to a new place. The materiality of place, figured as clean and orderly, presented its own distinctive resources that are then deployed in the cultivation of place, in the attachments that Victoria experienced in this new place. This point is further illustrated in one of the pictures taken by Maria, a single mother who arrived in Val Rendena
Putting Belonging into Place: Place

Experience and

Sense of

Belonging among

Ecuadorian

Migrants in an

Italian Alpine

Region 
in 200 I with her two children. One of Maria's photos portrays the village's main playground:

Here there are also playgrounds. This is a good thing. There [in Ecuador] there are some playgrounds but they are unkempt. People do not take care of them, they destroy them, they even steal the flowers. They do not take care of these things; this [to take care of things] is something good that we are learning living here. Children do not touch flowers, this is a positive thing. We have to inculcate these things; for example, if you eat something you do not have to throw the paper away. Here we have learned to live.

Flowers and playgrounds are not simple matters of fact. Embedded in their very materiality are social and somatic practices like civic awareness and respect for nature and beauty. Maria clearly values these practices and is looking to pass them on to her children. The resources afforded by the local playground are vital to the ongoing cultivation of place and to the affective dynamics of place attachment. The playground is a significant place for Maria precisely because it signifies home for her and her children.

Carla's pictures express a similar view. She arrived in Val Rendena in I999, after leaving Ecuador to earn money abroad to help support her mother and brothers. Initially, she missed Ecuador very much, but at the time of the interview Carla doubted that she would ever return. One of Carla's photographs depicts a non-descript section of a local footpath (see Figure 2). She explains that the photo depicts the exact place where the kindergarten bus stops:

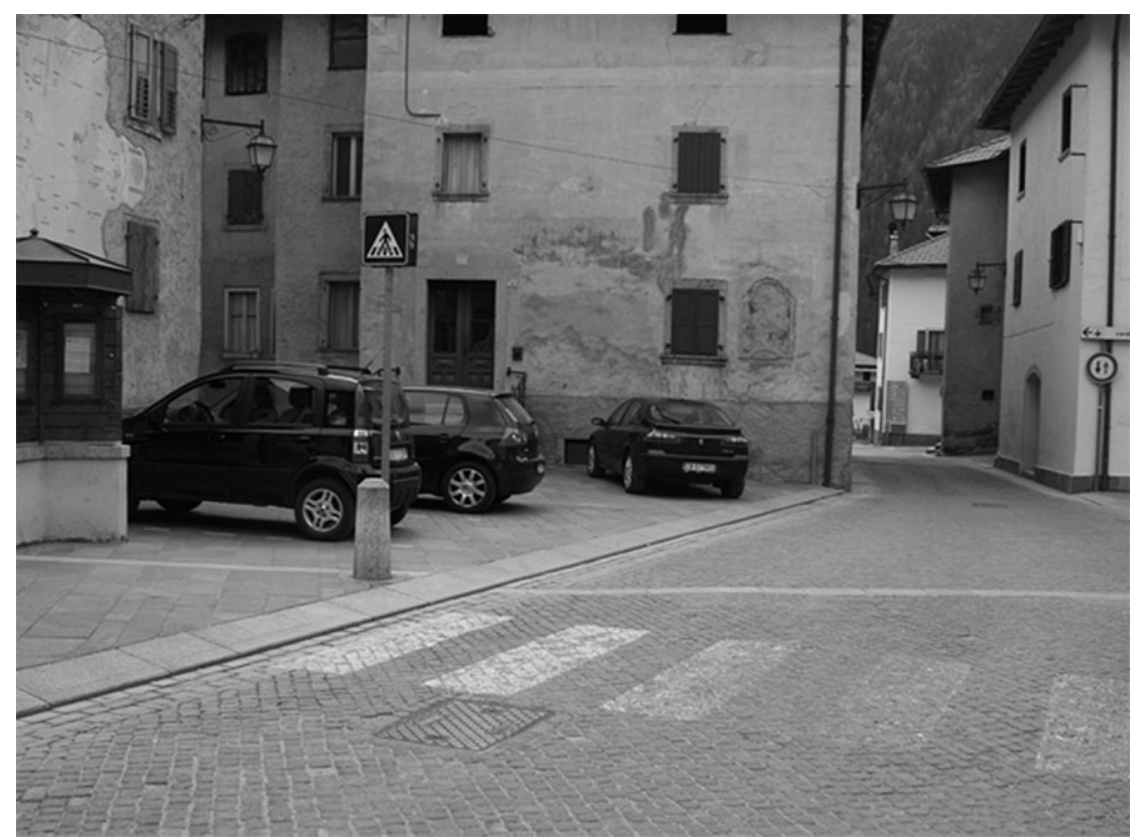

Figure 2. Maria's picture. A non-descript section of a local footpath. 
For me it is so good that there is something like the kindergarten bus. Everything is so well organized here. I just bring him [her child] to the bus stop and then I go back to pick him up at 4 p.m., they take care of all the rest.

The material features of Val Rendena such as the local playground and bus stops clearly have a significant impact on everyday life for our research participants. The clean streets, tidy gardens, parks, and local services all enhance the value of place, helping to galvanize a sense of belonging. The material affordances grounded in local parks, bus stops, and the broader services and civic programs that provide these resources may be regarded as formal constituents of this belonging to place.

\section{Place as affect}

$P^{2}$ omina, 27, who has lived in Val Rendena for three years, offers a poignant illustration of the affective dimensions of place-making in describing feelings that are inspired by visits to a local elementary school. Speaking of a photograph she took of the school, Romina comments:

Yes, I like to bring Victor [her child] here [at school] every morning. This helps me. I feel well when I arrive there, with all the other mums, and I see all these nice little boys and girls, all cleaned up, with their bags. I know I am doing the right thing, despite all the effort. We [she and her husband] miss Ecuador so much, my mum is old and [pause] but he [Victor] is the future. We can, anyway, go back [to Ecuador] when he has finished school, so he can find a good job with an Italian qualification, you know. With only an Ecuadorian qualification he would have no chances, you know.

Romina's story refers to an array of feelings associated with her experience at her son's school: pride in her son and hope for his future, satisfaction with the upkeep of the school, ambivalence about home, and comfort in the social contact of her adopted community, among other feelings. Much of these sentiments are caught up in Romina's hopes for the future and the prospect of more promising employment opportunities for her children. Adriana shares a similar story which highlights the affective power of place. Adriana, who had arrived in Val Rendena with her child ten years earlier, spoke of a picture she had taken of the local bank. She says that she has given up on the idea of working for the bank because employment vacancies are rare. Positions are held for a long time by the same person. Adriana feels that when one becomes open, it is quickly taken by a "local person." She accepts this, but she thinks her son will have greater job opportunities because "he is born here, he will grow up here, he will make friends here, and so he will have the opportunity to work in that bank." Places like schools and banks represent great hope for the future, particularly for the children of
Putting Belonging into Place: Place

Experience and Sense of

Belonging among Ecuadorian Migrants in an Italian Alpine Region 
Ecuadorian migrants who are expected to adopt Italian living standards and thus achieve what their parents could not.

These kinds of accounts suggest that our participants experience Val Rendena as an "enabling place" (Duff 2009: I I 8), and a place where their plans and aspirations may be achieved. Val Rendena makes them hopeful. In and through this hope, our participants speak of developing a sense of belonging, assigning specific meanings to place and drawing specific resources from it. Indeed, hope is one of the most important affects our participants describe in their accounts of Val Rendena. Participants' stories of hope emphasize the links between this affect and a more general tendency towards acting in and for the future (Thrift 2004). As Ben Anderson (2006:733-735) contends, as one becomes hopeful, a whole array of "capacities and capabilities are enabled," presenting a series of pathways and strategies for action. Certainly for our participants hope for a better future is a primary source of motivation to continue to struggle and work hard for a more prosperous future. Even so, our participants' accounts of their sources of hope reveal once more the critical role of place and place-making in sustaining the experience of hope. As we note above, it is not the natural beauty of Val Rendena that sustains hope for a better future among the Ecuadorian community. Rather it is Val Rendena's clean roads, trash collection, well-equipped hospitals, playgrounds, schools, and the reliable public transportation, banks and services. These amenities affect participants' perceptions of Val Rendena as a positive and enabling place. Moreover, participants speak of developing a sense of belonging to Val Rendena, in and through the diverse affects that sites within the region afford them. Overall, Val Rendena is described by many as a place of opportunity, a place for a better and more fulfilling life, good health, happiness and well-being, and a place that offers a better future. These sentiments are derived from various aspects of community life in Val Rendena, from particular attachments to local public spaces, and from a bourgeoning sense of belonging. Indeed, the importance participants ascribe to the social, material and affective dimensions of place sheds new light on the experience of belonging and place-attachment in a context of migration and displacement.

\section{Belonging: A social, material, and affective achievement}

n a seminal contribution to theories of space and place, Corsin-Jiménez (2003) points out that space is constituted in the distribution of material and social capacities. Corsin-Jiménez goes on to conceive of space as a carrier of value and meaning in terms of the discrete capacities it conveys or distributes. Certainly the reports of our participants bear out this argument, including, for example, the social events afforded in local parks and dance halls, routine garbage collection, the morning school bus route, and the affordances of the local playground. However, our data provide little support for Corsin-Jiménez subsequent differentiation (or 
disarticulation) of space from territoriality. Corsin-Jiménez argues that "it is no longer necessary to download meaning onto a territory or weave it into a land. Only then can we have spaces that bear no attachment to place" (2003:150). We share Lund and Benediktsson's (2010) concern that such an approach risks eliding the material, grounded aspects of space in favor of a symbolic, social, or discursive construction of place. Instead, our data reveal that the building blocks of place are found as much in the material or territorial constituents of space itself, as in the agentic work of motivation, exploration, and meaning-making. Our data also reveal that the sense that space is made not only of material and social capacities, but of affective ones too. Indeed our data suggest that belonging is a social and affective achievement that is necessarily linked to the materiality of specific territories. It follows that the material and social capacities associated with identity and belonging cannot be performed without an affective dimension, and without some affective attachment to place.

In this respect, the production of place is first and foremost the creation of a structure of feeling. As Sara Ahmed argues, migration implies "a spatial reconfiguration of an embodied self" through "the lived experience of locality" (I999:34I). This affective experience of place involves embodied encounters in and with place (Massumi 2002). Space establishes and invites encounters, sometimes forcing uninvited encounters. Yet it is never merely the ground of the encounter (Urry 2002). Our study strongly indicates that one of the most significant affective states associated with the experience of place and mobility is that of belonging - or not belonging - to the bodies, spaces, or territories one encounters in that mobility. For this reason, the affective states occasioned by place should be understood as substantial features of belonging (or not-belonging). As Seigworth and Gregg (2010:2) argue, "affect marks a body's belonging to a world of encounters, or a world's belonging to a body of encounters but also, in non-belonging, through all those far sadder (de)compositions of mutual in-compossibilities." An affective encounter is a specific crystallization of relations with unique intensive features. It is defined by the "inherently sticky pragmatics of right now, right here" (Highmore 2010:I4). Affect creates resonant affinities between body and place, thus establishing a means for bodies and places to "territorialize" one another (Grossberg 2010).

All the same, a territory should never be understood as an immutable surface; it is something that changes in and emerges from the relationality that is its primary constituent feature (Gregoric Bon 2010). When Clifford Geertz tried to describe the difficulties of establishing civil ties in ex-colonies, because they were inhabited by a population still enthralled by "primordial" attachments, he listed kinship, race, religion, habits, language and territory as social and cultural "facts" capable of promoting a stronger connection to place. After the Second World War however, the assumption that identity derives from a deep-rooted association with territory has come to be seen as the original vice of national intolerances. Concepts of territoriality are certainly out of favor; they
Putting Belonging into Place: Place

Experience and Sense of

Belonging among Ecuadorian

Migrants in an Italian Alpine Region

Place is first and foremost the creation of a structure of feeling 
have lost legitimacy in scholarly debates and their conceptual space has been overtaken by a world made of flows. Still others have attempted to retain the notion of territory, often with a Deleuzian flavor, by reconceiving territory as a post-national space where its materiality and meaning blossom through people and place enactments and engagements (Thrift 2004). Reflecting on our ethnographic data, we wish to argue for the retention of territory by insisting that the idea of territory need not necessarily remain politically or culturally reactionary. Territory emerges in our data as a practice through which belonging is shaped, imagined, articulated, and enacted. To echo Nash's words: "what may be a politically regressive turn to ethnic purity and racial discourse in one context can, in another, productively unsettle exclusive versions of belonging" (2002:48). The political question does not concern the ideological content of the concept of territory. Rather, it is one of determining the political project that the concept of territory (or territorialization) in its re-workings might endorse.

\section{Conclusion}

\rceil

he intimate portrait of spatial, social and affective practices provided by our participants reveals much of the everyday experience of place and belonging among migrant communities in Val Rendena. By highlighting the role of social, material, and affective attachments in the work of place-making we have sought to unveil something of the mechanics of belonging in place. The ethnographic account of these processes introduced above emphasizes the emplacement of material, social, and affective practices, and the ways these practices are used to produce and reproduce an experience of home and belonging. Our analysis indicates that while families miss the social relationships and places they left behind, most have decided to stay permanently, giving up the "myth of return." Participants state that Val Rendena offers more opportunities in term of employment, education, and access to services than Ecuador. Yet the decision to stay in Val Rendena is based on more than a simple assessment of economic advantage. As we have noted, participants describe a slowly unfolding sense of belonging to place, with strong emotional or affective dimensions. Even as participants insist that they remain "Ecuadorian," they speak of a special attachment to the very materiality of place in Val Rendena. This attachment may be regarded as an assemblage of social, material and affective resonances, experiences and practices, revealing something of the place of belonging. As such, the Ecuadorian sense of belonging does not rely on an abstract conception of cultural affiliation or contrast (i.e., Italian versus Ecuadorian culture); nor is it a purely psychological response. Rather, belonging accrues through a particular set of practices, through specific ways of inhabiting place. Another way of saying this is to emphasize the role of territorialization in the everyday work of belonging.

Certainly, we have no wish to revive an ideological concept of territory, but we do wish to stress that materiality, sociality, and 
affectivity are grounded in a specific territory, which mediates attachment and the sense of belonging. The significance of territory has to be acknowledged, observing at the same time that territory has no essential consistency in and for itself. Territory should never be reduced to some invariant, pre-cultural natural fact able to impose upon actors its meanings independent of the work of territorialization (Deleuze and Guattari 1987). In other words, there is nothing predictable about territory. As it is enacted by different actors, both human and non-human, its meaning, its character, and its social and political contexts will change. Territory emerges from the encounters of different resources and actors, and it is for this reason that we would insist that affect is a crucial aspect of the production of space and territory. Territory, intended as a specific configuration of social, material, and affective practices, is crucial for belonging, so long as we refuse to regard territory as a static surface, and instead see it as a meeting-up of histories, a coeval site of multiplicities in the making (Massey 2005).

Like much contemporary analysis (see Thrift 2004), our study suggests the need to reject understandings of belonging which rely on an intangible "sense of place" or psychological concepts of rootedness, in favor of more careful examination of the practicing of place. The focus on affect as an embodied, material, and relational capacity, which conveys at the same time a distinctive feeling state or transition in such states, delivers on our initial intention to acknowledge the material and subjective dimension of place, considering space as a "more-than-human-materiality" (Lund and Benediktsson 20I0:I), and as more-than-territoriality. The Cartesian dichotomy between res-extensa and res-cogitans no longer holds for space, and belonging may never be reduced to issues of materiality or territory. They are equally concerned with affect and practice.

\section{Notes}

Acknowledgements. The first author completed the fieldwork and developed the major themes and arguments, while the second author provided a conceptual framework to contextualize ethnographic data and contributed to the theoretical perspective of the paper.

'We thank the Servizio Statistica della Provincia di Trento for providing statistical figures of the presence of the Ecuadorian population in Val Rendena.

\section{References Cited}

Ahmed, Sara

I999 Home and Away: Narratives of Migration and Estrangement. International Journal of Cultural Studies 2(3):329-347.

Ambrosini, M., P. Boccagni, and S. Piovesan

20 I I L'immigrazione in Trentino. Rapporto annuale 20 I. CINFORMI. 
Anderson, Ben

2006 Becoming and Being Hopeful: Towards a Theory of Affect. Environment and

Planning D: Society and Space 24(5):733-752.

Anderson, Ben and Paul. Harrison

20 Iо Taking-place: Non-Representational Theories and Geography. London:

Ashgate.

Anwar, Muhammad

I979 The Myth of Return: Pakistanis in Britain. London: Heinemann.

Appadurai, Arjun

I988 Introduction: place and voice in anthropological theory. Cultural Anthropology 3:I6-20.

Arnoldi, Christian

2009 Tristi Montagne: Guida ai malesseri alpini [Sad mountains: A guide to alpine malaises]. Scarmagno (Torino): Priuli \& Verlucca ed.

Boccagni, Paolo

2010 Whom Should We Help First? Transnational Helping Practices in Ecuadorian Migration International Migration: $\mathrm{I}-26$.

20 I ra Migrants' Social Protection as a Transnational Process: Public Policies and

Emigrant Initiative in the Case of Ecuador. International Journal of Social Welfare 20(3):318-325.

20 I Ib Reminiscences, Patriotism, Participation: Approaching External Voting in Ecuadorian Immigration to Italy. International Migration 49(3):76-98.

Castells, Manuel

I977 The Urban Question. London, UK: Edward Arnold.

Clarke, Adele

2005 Situational Analysis: Grounded Theory After the Postmodern Turn.

Thousand Oaks, CA: Sage.

Clifford, James

I997 Routes: Travel and Translation in the Late Twentieth Century. Cambridge, MA: Harvard University Press.

Colombo, Asher, and Giuseppe. Sciortino

2004 Italian Immigration: The Origins, Nature and Evolution of Italy's Migratory

Systems. Journal of Modern Italian Studies 9(I ):49-70.

Conradson, David

2005 Landscape, Care and the Relational Self: Therapeutic Encounters in Rural England. Health \& Place I I:337-348.

Corsin Jiménez, Alberto

2003 On Space as Capacity. Journal of the Royal Anthropological Institute 9:137-I53.

Cummins, Sarah and Sarah Curtis, Ana V. Diez-Roux, Sally Macintyre 2007 Understanding and Representing Place in Health Research: A Relational Approach. Social Science \& Medicine 65( Iо):1825-1838.

Deleuze, Gilles and Félix Guattari

I987 A Thousand Plateaus: Capitalism and Schizophrenia. B. Massumi, transl. Minnesota, MN: University of Minnesota Press.

Duff, Cameron

2009 The Drifting City: The Role of Affect and Repair in the Development of Enabling Environments. International Journal of Drug Policy 20(3): I I 8-I 29.

Fogel, Alan., Barbara. King, and Stuart. Shanker, eds.

2008 Human Development in the Twenty-First Century: Visionary Ideas from Systems Scientists. Cambridge, UK: Cambridge University Press.

Geschiere, Peter

2009 The Perils of Belonging. Autochtony, Citizenship and Exclusion in Africa and Europe. Chicago, IL and London, UK: Chicago University Press. 
Gesler, Wilbert

1992 Therapeutic Landscapes: Medical Issues in Light of the New Cultural

Geography. Social Sciences and Medicine 34(7):735-746.

Gieryn, Thomas F.

2000 A Space for Place in Sociology. Annual Review of Sociology 26:463-496.

Gregoric Bon, Natasa

20 Io Migrant Routes and Local Roots: Negotiating Property in Dhermi/Drimades of Southern Albania. In Local Lives: Migration and the Politics of Place. Pp.I 7-30. B. Boenisch-Brednich and C. Trundle, eds. Surrey, UK: Ashgate.

Grossberg, Lawrence

2010 Affect's Future: Rediscovering the Virtual in the Actual. In The Affect Theory Reader. M. Gregg and G. J. Seigworth, eds. Pp.309-338. Durham, NC and London, UK: Duke University Press.

Gupta, Akhil and James Ferguson

I 997 Beyond "Culture": Space, Identity, and the Politics of Difference. In Culture, Power, Place: Exploration in Critical Anthropology. A. Gupta, J., Ferguson, eds. Pp.33-52. Durham, NC: Duke University Press.

Gustafson, Per

2006 Place Attachment and Mobility. In Multiple Dwelling and Tourism: Negotiating Place, Home and Identity. N. McIntyre, D. Williams, and K. McHug, eds. Pp.i 7-3 I. Cambridge, MA: CAB International.

Hage, Ghassan

2005 A Not So Multi-Sited Ethnography of a Not So Imagined Community. Anthropological Theory 5(4):463-475.

Hartig, Terry., and Henk Staats

2003 Guest Editors' Introduction. Theme issue, "Restorative Environments," Journal of Environmental Psychology 23:103-107.

Harvey, David

I973 Social Justice and the City. London: Edward Arnold.

Hastrup, Kirsten and Karen Folg Olwig

I997 Introduction. In Siting Culture. The Shifting Anthropological Object.

Karen Fog Olwig and Kirsten Hastrup, eds. Pp.I-I4. London, UK and New York, NY: Routledge.

Highmore, Ben

20 Io Bitter After Taste. Affect, Food, and Social Aesthetics. In The Affect Theory reader. M. Gregg and G. J. Seigworth, eds. Pp.ri 8-137. Durham, NC and London, UK: Duke University Press.

Johannesdottir, Guobjorg

2010 Landscape and Aesthetic Values: Not Only in the Eye of the Beholder. In Conversations with Landscape. K. Benediktsson and K. A. Lund, eds. Pp. I09-I 24. Surrey, UK: Ashgate.

Kahn, Miriam

I990 Stone-faced Ancestors: The Spatial Anchoring of Myth in Wamira, Papua

New Guinea. Ethnology 29:5 I-66.

Korpela, Kalevi and Terry Hartig

I 996 Restorative Qualities of Favorite Places. Journal of Environmental Psychol-

ogy I 6:22 I-233.

Krause, Kristine and Katherina Schramm

20 I I Thinking Through Political Subjectivity. African Diaspora 4:I I 5-I34.

Lawrence, Denise and Setha Low

I990 The Built Environment and Spatial Form. Annual Reviews in Anthropology

I 9:453-505.
Putting Belonging

into Place: Place

Experience and

Sense of

Belonging among

Ecuadorian

Migrants in an

Italian Alpine

Region 
Leach, James

2006 "Team Spirit": The Pervasive Influence of Place-Generation in "Community

Building" Activities along the Rai Coast of Papua New Guinea. Journal of

Material Culture I I (I-2):87-I03.

Leenhardt, Maurice

I979 [1947] Do Kamo: Person and Myth in the Melanesian World. Chicago, IL: Chicago University Press.

Liamputtong, Pranee and Douglas Ezzy

2005 Qualitative Research Methods. South Melbourne, AU: Oxford University Press.

Lund, Katrin Anna and Karl Benediktsson

20 Io Introduction: Starting a Conversation with Landscape. In Conversations with Landscape. Karl Benediktsson and Katrin Anna Lund, eds. Pp.I-I2. Surrey, UK: Ashgate.

Macintyre, Stuart, Anne. Ellaway and Sarah. Cummins

2002 Place Effects on Health: How Can We Conceptualize, Operationalize and Measure Them? Social Science \& Medicine 55(I):I25-I39.

Malpas, Jeff

2012 Putting Space in Place: Philosophical Topography and Relational Geography. Environment and Planning $\mathrm{D}_{30}(2): 226-242$.

Marcus, George

I989 Imagining the Whole: Ethnography's Contemporary Efforts to Situate Itself.

Critique of Anthropology 9(3):7-30.

Massey, Doreen

2005 For Space. London, UK: Sage.

Massumi, Brian

2002 Parables for the Virtual: Movement, Affect, Sensation. Durham: Duke University Press.

Myers, Fred. R.

2000 Ways of Place-making. In Culture, Landscape and the Environment: The

Linacre Lectures. K. Flint and H. Morphy, eds. Pp.72-1 Io. Oxford: Oxford University Press.

Nash, Catherine

2002 Genealogic Identities. Environment and Planning D: Society and Space 20:27-52.

Nyamnojoh, Francis B. and Peter Geschiere

2000 Capitalism and Autochtony. The Seesaw of Mobility and Belonging. Public Culture I2(2):423-452.

Pallares, Amalia

2005 Ecuadorian Immigrants and Symbolic Nationalism in Chicago. Latino Studies 3:347-37I.

Pink, Sarah

2006 The Future of Visual Anthropology: Engaging the Senses. Oxford,UK: Routledge.

Rodman, Margaret. C.

1992 Empowering Place: Multilocality and Multivocality. American Anthropologist $94(3): 640-656$.

Sciortino, Giuseppe, and Asher Colombo

2003 Introduzione [Introduction]. In Stranieri in Italia. Un'immigrazione normale [Foreigners in Italy. A normal immigration]. G. Sciortino and A. Colombo, eds. Bologna: Il Mulino.

2004 The Flows and the Flood: The Public Discourse on Immigration in Italy, I969-200 I Journal of Modern Italian Studies 9(I):94-I I3. 
Seigworth, Greg and Melissa Gregg

2010 An Inventory of Shimmers. In The Affect Theory Reader. M. Gregg and G. J. Seigworth, eds. Pp.I-28. Durham, NC and London, UK: Duke University Press.

Tawil, Oussama., Annette Verster and Kevin O'Reilly

I995 Enabling Approaches for HIV/AIDS Prevention: Can We Modify the Environment and Minimize the Risk? AIDS 9(12):1299-1306.

Thrift, Nigel

2004 Intensities of Feeling: Toward a Spatial Politics of Affect. Geografiska Annaler. Series B: Human Geography 86 B(I):57-78.

Tolia-Kelly, Divya. P.

2007 Fear in Paradise: The Affective Registers of the English Lake District Landscape Re-visited. Senses and Society 2(3):329-35I.

Urry, John

2002 Mobility and Proximity. Sociology 36(2):255-274.

Wang, Caroline and Mary Ann Burris

I997 Photovoice: Concept, Methodology, and Use for Participatory Needs Assessment. Health Education \& Behavior 24(3):369-387.

Williams, Alison, ed.

I999 Therapeutic Landscapes: The Dynamic Between Place and Wellness.

Lanham, MD: University Press of America.

2007 Therapeutic Landscapes. London, UK: Ashgate.

Woolley, Charles

2009 Meeting the Mixed Methods Challenge of Integration in a Sociological Study of Structure and Agency. Journal of Mixed Methods Research 3(I):725.

Yin, Robert

2006 Mixed Methods Research: Are the Methods Genuinely Integrated or Merely Parallel? Research in the Schools I3 $(\mathrm{I}): 4 \mathrm{I}-47$.

Yuval-Davis, Nira

2004 Borders, Boundaries and the Politics of Belonging. In Ethnicity, Nationalism and Minority Rights. Stephen May, Tariq Modood, and Judith Squires, eds. Pp.2 I4-230. Cambridge, UK: Cambridge University Press.

2006 Belonging and the Politics of Belonging. Patterns of Prejudice 40(3):197$2 \mathrm{I} 4$.
Putting Belonging

into Place: Place

Experience and

Sense of

Belonging among

Ecuadorian

Migrants in an

Italian Alpine

Region 